\title{
Bacterial Candidates for Colonization and Degradation of Marine Plastic Debris
}

\author{
Roager, Line; Sonnenschein, Eva C.
}

\section{Published in:}

Environmental Science and Technology

Link to article, DOI:

10.1021/acs.est.9b02212

Publication date:

2019

Document Version

Peer reviewed version

Link back to DTU Orbit

Citation (APA):

Roager, L., \& Sonnenschein, E. C. (2019). Bacterial Candidates for Colonization and Degradation of Marine Plastic Debris. Environmental Science and Technology, 53(20), 11636-11643.

https://doi.org/10.1021/acs.est.9b02212

\section{General rights}

Copyright and moral rights for the publications made accessible in the public portal are retained by the authors and/or other copyright owners and it is a condition of accessing publications that users recognise and abide by the legal requirements associated with these rights.

- Users may download and print one copy of any publication from the public portal for the purpose of private study or research.

- You may not further distribute the material or use it for any profit-making activity or commercial gain

- You may freely distribute the URL identifying the publication in the public portal

If you believe that this document breaches copyright please contact us providing details, and we will remove access to the work immediately and investigate your claim. 


\section{Bacterial Candidates for Colonization and}

2 Degradation of Marine Plastic Debris

3 Line Roager ${ }^{1}$, Eva C. Sonnenschein ${ }^{1 *}$

4 * corresponding author

$5{ }^{1}$ Technical University of Denmark, Department of Biotechnology and Biomedicine, Søltofts

$6 \quad$ Plads 221, 2800 Kgs. Lyngby, Denmark

8 Marine bacteria; bioremediation; plastic pollution; biodegradation; plastic

10 ABSTRACT. With the rising plastic pollution in the oceans, research on the plastisphere - the

11 microorganisms interacting with marine plastic debris - has emerged. Microbial communities

12 colonizing plastic have been characterized from several ocean regions and they are distinct from

13 the communities of the surrounding waters and a few plastic-degrading microorganisms have been

14 isolated from other environments. Therefore, we propose that marine microorganisms have

15 adapted to plastic as a surface for colonization and potentially degradation. When comparing the

16 taxonomic patterns of plastic-associated, marine bacteria, recurring groups and families such as

17 the families Erythrobacteraceae and Rhodobacteraceae (Alphaproteobacteria), Flavobacteriaceae 
18 (Bacteriodetes) and the phylum of Cyanobacteria (such as the Phormidium genus) can be

19 identified. Thereby, we provide a perspective on which bacterial candidates could play a role in

20 the colonization and possible degradation of plastic in the oceans due to their occurrence on marine

21 plastic debris. We emphasize the need for extended and reproducible collection of data to assess

22 the existence of a core microbiome or core functionalities of the plastisphere and confirm the

23 capability of these bacterial candidates for biodegradation of plastic. Furthermore, we suggest the

24 next steps in research to elucidate the level of natural bioremediation and the exploitation of

25 bacterial degradative mechanisms of plastic.

\section{Introduction}

In recent years, the problem of plastic pollution has gained growing public and scientific

29 attention. The global plastic demand increased from 1.5 million tons in the 1950 s to 335 million

30 tons in $2016^{1}$ with an estimated $50 \%$ of plastic products being disposable ${ }^{2}$. Due to incorrect

31 disposal or spill during production or transport, plastics can enter the marine environment where

32 they are persistent pollutants. ${ }^{3,4}$ An estimated 4.8 to 12.7 million tons of plastic enter the ocean

33 per year. ${ }^{5}$ Today, between 80 and $85 \%$ of marine litter is made up of plastic, ${ }^{6,7}$ and both macro-

$34(>5 \mathrm{~mm})$ and microplastics $(<5 \mathrm{~mm})$ can be a threat to marine wildlife due to entanglement or

35 ingestion. ${ }^{2,8}$ Additionally, plastic additives, climate-relevant trace gases, or dissolved organic

36 carbon leaching from the plastic can - potentially negatively - affect the environment. ${ }^{8-11}$ While

37 abiotic fragmentation of plastic does occur in the ocean due to wave action, oxidation, and

38 photo-oxidation, ${ }^{12}$ the actual rate of degradation in the marine environment and the ultimate fate

39 of plastic remains unresolved. ${ }^{2,13-15}$ The amount of plastic entering the marine system exceeds 
40 the amount of plastic detected in the surface ocean ${ }^{16}$ and therefore, biofouling and

41 biodegradation have been proposed as processes of plastic removal from surface waters. ${ }^{13,17}$

42 Recently, both fungi and bacteria have been proposed to or even identified to degrade different

43 types of plastic from primarily terrestrial sources. ${ }^{17-30}$ In the marine environment, our current

44 knowledge is primarily limited to the microbial diversity of communities colonizing plastic

45 surfaces ${ }^{31-40}$. However, marine bacteria are capable of degrading natural hydrocarbons from e.g.

46 oil spills or cellular lipids and are proposed to play a major role in the ocean's hydrocarbon

47 cycle. ${ }^{41,42}$ Since the ocean is experiencing such high level of plastic pollution, we propose that

48 marine microorganisms may also evolve to utilize this new carbon source. Biodegradation of

49 plastic by microorganisms and their enzymes could present a way of natural bioremediation and

50 possibly affect the global plastic pollution. Additionally, controlled application of these

51 mechanisms could facilitate reduction of the plastic persistence in the environment and could -

52 with the improvements that today's synthetic biology can provide ${ }^{43,44}$ - be implemented in cell

53 factory design for employment in a circular economy. ${ }^{45-48}$

54 With our current state of knowledge, what are the best bacterial candidates for colonization

55 and degradation of marine plastic litter? We will address this question by summarizing the

56 studied bacteria associated with marine plastic debris either as colonizers or as degraders, and

57 give a perspective, on which taxonomic groups are of particular interest for future investigation

58 regarding bacterial biodegradation of the following 'non-biodegradable' plastics: polystyrene

59 (PS), polypropylene (PP), polyethylene (PE), and polyethylene terephthalate (PET). The so-

60 called biodegradable plastic types and associated bacteria will not be further discussed in the

61 present work (recently reviewed by Emadian et al. ${ }^{49}$ ), as our target is commercial, synthetic 
62 plastic that constitutes the vast majority of plastic debris in the oceans. ${ }^{50}$ Since fungi are largely

63 outnumbered by bacteria in the oceans, ${ }^{51,52}$ this work focuses on bacteria.

65 Colonization of marine plastic debris by microorganisms was first described in $1972^{53,54}$ and 66 in recent years, an increasing number of studies have investigated the composition of microbial

67 communities with regards to their taxonomic units. Bacterial communities inhabiting the surfaces

68 of marine plastic debris differ significantly from the communities in the pelagic waters around

69 them or on other particle types. ${ }^{31,33,37-40}$ Certain bacterial groups belonging to the phyla

70 Proteobacteria, Bacteroidetes, Firmicutes, and Cyanobacteria (Table 1) appear to be enriched on

71 plastic more often than others, suggesting that this is an ecological niche beneficial for specific

72 taxonomic groups and indicating a potential metabolic adaptation (e.g. attachment, chemotaxis,

73 additive resistance, degradation) to the material. If these bacteria have developed enzymatic

74 mechanisms for the degradation of plastic, these bacterial groups are of specific interest for

75 bioremediation and bioengineering purposes.

76 Table 1. Bacterial families re-occurring on marine plastic debris as identified by sequenced-

77 based analysis of microbial diversity, plastic type, sampling site.

\begin{tabular}{|c|c|c|c|c|c|}
\hline family & order & class & plastic type & sampling site & reference \\
\hline \multirow[t]{5}{*}{ Flavobacteriaceae } & Flavobacteriales & Flavo-bacteria $^{1}$ & PE, PET, PP, & North Sea, Baltic Sea, & $33,35-37,39,55-57$ \\
\hline & & & PS & Mediterranean Sea, North & \\
\hline & & & & Atlantic Ocean, Humber & \\
\hline & & & & Estuary, North Pacific & \\
\hline & & & & Ocean & \\
\hline
\end{tabular}




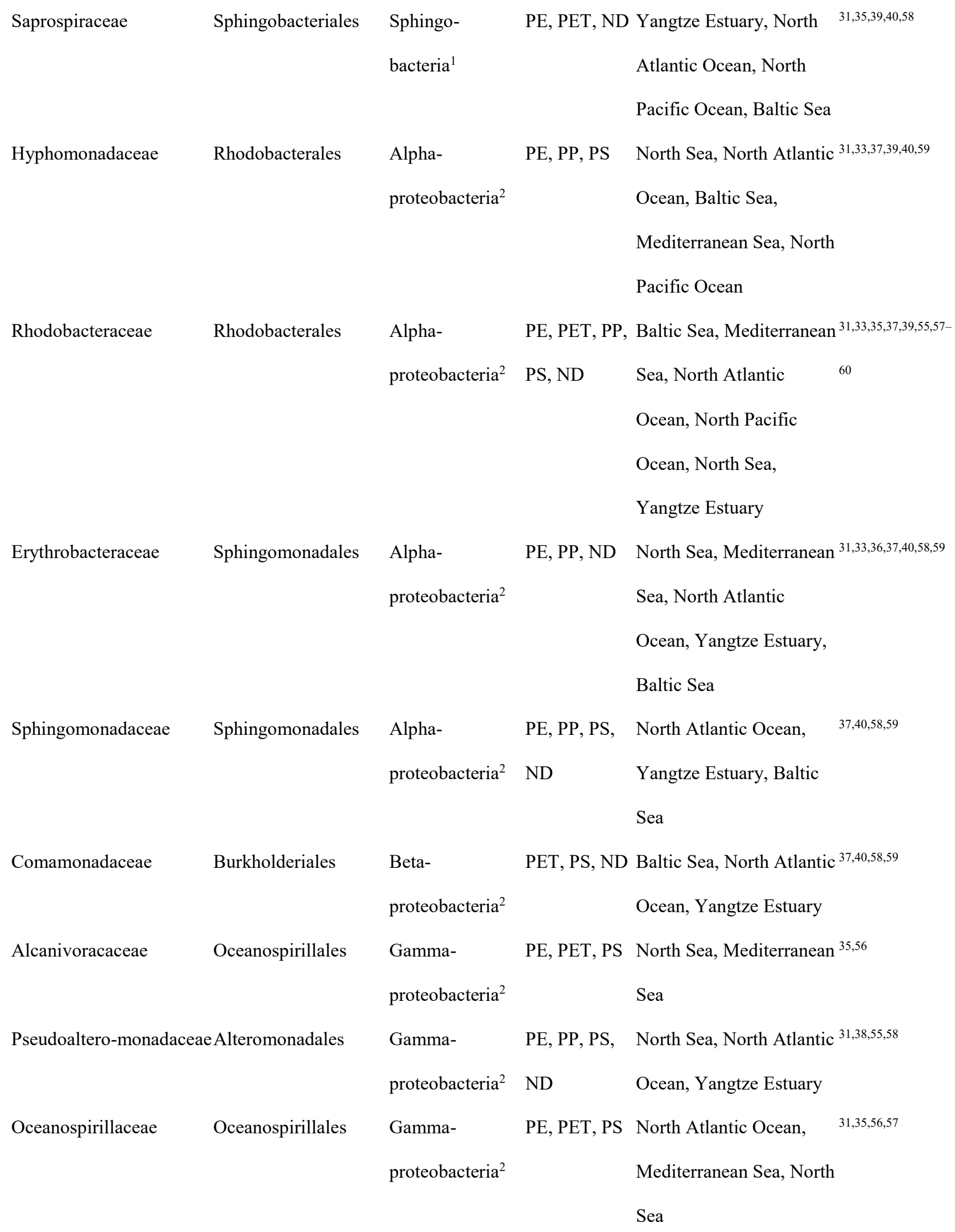


Vibrionaceae

Vibrionales

Gamma-

PE, PP, PS North Sea, North Atlantic ${ }^{31,38,55}$

proteobacteria $^{2}$

Ocean

${ }^{1}$ phylum of Bacteroidetes; ${ }^{2}$ phylum of Proteobacteria; ND = not defined.

2.1 Proteobacteria. The globally most abundant phylum of Proteobacteria also comprises the

81 most observed phylum on marine plastic debris compared to seawater. ${ }^{36,38,40,56,57}$ This phylum

82 has observed with a higher abundance on plastic surfaces compared to glass and organic

83 surfaces. ${ }^{40}$ Within this phylum, the classes of Alphaproteobacteria, Gammaproteobacteria and in

84 some cases, of Betaproteobacteria and Deltaproteobacteria are enriched on plastic

85 samples. ${ }^{39,56,59,61}$ The alphaproteobacterial family of Hyphomonadaceae contains members

86 known as methylotrophs, hydrocarbon degraders, and members isolated from hydrocarbon-

87 enriched environments and are also abundant colonizers of PP, PS, and PE. ${ }^{31,33,37,39,40,59}$ Some

88 species have even developed a "holdfast" dedicated and essential for surface attachment

89 demonstrating their adaptation to a sessile life stage. ${ }^{62}$ Compared to colonization of wooden

90 pellets, the Hyphomonadaceae family was significantly associated with PE and PS. ${ }^{37}$ Another

91 alphaproteobacterial family commonly colonizing marine plastic is

92 Rhodobacteraceae. ${ }^{31,33,35,37,39,40,55,57-60}$ This family is known as "initial colonizers" of various

93 substrates in the marine environment ${ }^{63}$ indicating a non-specificity for plastic. In a recent study,

94 this family was found more frequently on marine plastic debris compared to organic particles. ${ }^{33}$

95 The common marine plastic-colonizing family of Erythrobacteraceae has been identified on PP,

96 PS, PE and PET and was found on both macro- and microplastics. ${ }^{31,33,36,37,40,58,59}$ They are known

97 to be capable of degrading polycyclic aromatic hydrocarbons (PAHs) that can be associated with

98 plastic and could explain their increased abundance ${ }^{64}$. Erythrobacteraceae have been identified as 
99 significantly enriched on PE compared to wooden pellets, ${ }^{37}$ but has also been found in high 100 abundances on organic particles isolated from the marine environment compared to non-specific 101 plastic types. ${ }^{33}$

102 Within the Gammaproteobacteria, orders like the Pseudomonadales have been highlighted by 103 several research groups. ${ }^{31,35,37}$ Species of the Pseudomonas genus isolated from soil and waste 104 sites have previously been identified as degraders of plastic, ${ }^{18,19,25,28,65,66}$ making this genus of 105 specific interest for future research. The order of Oceanospirillales has also been found in 106 association with plastic by several studies, ${ }^{35,55-57,67}$ and the family of Alcanivoraceae stands out 107 as significantly associated with PE, PET and PS. ${ }^{35,56}$ Members of this family were more 108 frequently found on plastics compared to glass beads. ${ }^{35}$ The type genus of this family,

109 Alcanivorax, forms biofilms in marine environments and has genomic capacity to degrade 110 several oil-derived hydrocarbons. ${ }^{68}$ Members of the genus Vibrio were also detected on plastic 111 surface samples when compared to the free-living community, however they are also present on 112 many other marine surfaces..$^{31,34,38,55,69}$ Strains of this group have been found to degrade $\mathrm{PAHs}^{70}$ 113 and the group is very well studied for its ability to degrade the natural polymer chitin. ${ }^{71,72}$

114 The most prevalent order colonizing marine plastic debris within the Betaproteobacteria is the 115 Burkholderiales..$^{37,40,58,59}$ This order has been found to be significantly enriched on plastic beads 116 compared to glass beads and cellulose. ${ }^{40}$ An especially abundant genus is Hydrogenophaga, of 117 which species have been observed as colonizers of PE, PP, and PS. ${ }^{37,40}$ Species belonging to the 118 Burkholderiales order have previously been shown to degrade petroleate derivatives. ${ }^{73}$ The 119 Ideonella sakaiensis strain capable of degrading $\mathrm{PET}^{26}$ belongs to the Betaproteobacteria class, 120 but no strains of this species have been detected as colonizers of marine plastic debris. 
121 One order within the class of Deltaproteobacteria has been reported several times as

122 colonizers of plastic in the oceans, the Myxococcales order. ${ }^{31,35,37,40}$ This order is known for its

123 ability to produce hydrolytic enzymes and decompose various polymers, ${ }^{74}$ which is of interest

124 regarding their potential degradation of plastic polymers.

125 2.2 Bacteriodetes. The Bacteriodetes phylum can be enriched on plastic surfaces. ${ }^{31,36,38,59}$

126 Especially, the order of Flavobacteriales has been found as colonizers on PS, (LD)PE, PP, and

127 PET. ${ }^{31,33,35-37,39,55-57}$ The genus Flavobacterium has previously been associated with plastic in

128 other environments than the marine. ${ }^{56,65}$ Another genus, Tenacibaculum, has repeatedly been

129 found in significantly high abundances on plastic surfaces in marine environments. ${ }^{31,35-37,39,55,59}$

130 This genus contains species known as degraders of the polyester polycaprolactone, which is a so-

131 called biodegradable plastic type. ${ }^{75}$ A species of Flavobacteriales, Ulvibacter litoralis, was found

132 exclusively on plastic particles compared to bacteria isolated from the water column and organic

133 particles. ${ }^{33}$ Additionally, the Flavobacteriaceae family was found more frequently on PET

134 particles compared to glass beads ${ }^{35}$ as well as on PE and PS compared to wooden pellets. ${ }^{37}$ The

135 order Sphingobacteriales has also frequently been identified as colonizers of plastic, with the

136 Lewinella genus as the most prevalent one, but also many bacteria unclassified at genus level

137 belonging to the order have been associated with different types of plastics such as PS, PE, PET,

138 and PP. ${ }^{31,35,39,40,58,59}$ Some species belonging to the Sphingobacteriales order are capable of

139 metabolizing PAHs,${ }^{76}$ making them particularly interesting with regards to potential

140 bioremediation of specific plastic components.

$141 \quad 2.3$ Firmicutes and Cyanobacteria. The Bacillaceae family of the Firmicutes phylum was

142 identified as significantly enriched on marine PS samples by Syranidou et al. ${ }^{56}$ in accordance

143 with the marine bacterial degraders of plastic already found (Table 2). Cyanobacteria have been 
144 observed as significantly enriched on various types of plastic, ${ }^{33,36,39,59}$ e.g. Phormidium species

145 have been found on PE, PET, and PP samples $31,33,35,36,39,58,59$ and are known to degrade

146 hydrocarbons. ${ }^{77}$ Since Cyanobacteria are photosynthetic organisms, the benefit of higher sunlight

147 exposure on floating plastic pieces might however be the actual reason for their enrichment on 148 plastic debris.

\section{Marine Plastic-Degrading Bacteria}

In 2016, Yoshida et al. isolated a novel bacterial strain, Ideonella sakaiensis 201-F6, from a

151 PET bottle recycling site that is able to both degrade and assimilate highly crystallized PET. ${ }^{26}$ In

152 contrast to this extraordinary finding and subsequent optimization of the PETase enzyme, ${ }^{46}$ our

153 knowledge on plastic-degrading marine bacteria and their enzymes is very limited and awaits

154 confirmation of the metabolic mechanisms. The limited information available was recently

155 reviewed by Jacquin et al. ${ }^{78}$ Whereas biodegradation of PET under aerobic conditions is known

156 to be initiated by the PETase enzyme, ${ }^{26}$ the most common biodegradation pathway for PS is

157 initiated by a styrene monooxygenase. ${ }^{78}$ For PP and PE such information is not available, but it is

158 generally thought that PE biodegradation is initiated by either biotic or abiotic oxidation of the

159 PE chain, and oxidoreductases, laccases and an alkane hydroxylase have been found to play

160 central roles. ${ }^{78,79}$ Sudhakar et al. discovered two marine Bacillus strains capable of degrading

161 low-density and high-density polyethylene (LDPE and HDPE) in 2008 (Table 2). ${ }^{80}$ However,

162 this degradation happened at very low rates with a maximum weight loss of $10 \%$ and $3.5 \%$ for

163 LDPE and HDPE, respectively, after 1 year. If the plastic samples were pretreated thermally, the

164 percentage of weight loss increased significantly, indicating that preceding weathering of plastic

165 might make it more accessible for biodegradation by bacteria. ${ }^{80}$ Further marine plastic degraders

166 belonging to the Bacillus genus have been isolated from mangrove sediment. ${ }^{81} \mathrm{~A} B$. cereus strain 
167 was able to degrade both PE, PET and PS microplastics at rates of $1.6 \%, 6.6 \%$, and $7.4 \%$ weight

168 loss, respectively, in 40 days. A B. gottheilii strain degraded PE, PET, PS, and PP at rates of

$1696.2 \%, 3.0 \%, 5.8 \%$, and $3.6 \%$ weight loss, respectively, in 40 days. ${ }^{81}$ A third strain, Bacillus $s p$.

17027 , was able to degrade PP at a rate of $4 \%$ in 40 days. ${ }^{82}$ Two other marine Bacilli, B. pumilus

171 M27 and B. subtilis H1584, isolated from coastal waters of the Arabian Sea were able to degrade

172 LDPE at rates of $1.5 \%$ and $1.75 \%$ in 30 days, respectively. ${ }^{83}$ Gram-positive plastic-degrading

173 bacterial isolates include the marine Rhodococcus sp. strain 36 (degradation of PP with $6.4 \%$

174 weight loss in 40 days) ${ }^{82}$ and the Kocuria palustris strain M16 (degradation of LDPE with $1 \%$

175 weight loss in 30 days). ${ }^{83}$

176 Table 2. List of suggested plastic-degrading marine bacteria, degraded plastic type,

177 degradation rate and origin of isolate.

\begin{tabular}{|c|c|c|c|c|c|c|}
\hline class & species and & $\% \mathrm{w}$ & duration of & \% weigh & origin of & reference \\
\hline & plastic type & loss & experiment & per year & $\begin{array}{l}\text { bacterial } \\
\text { sample }\end{array}$ & \\
\hline Actinobacteria & $\begin{array}{l}\text { Kocuria palustris LDPE } \\
\text { M16 }\end{array}$ & 1 & 30 days & 12.2 & $\begin{array}{l}\text { Seawater, } \\
\text { Arabian Sea }\end{array}$ & 83 \\
\hline & $\begin{array}{l}\text { Rhodococcus sp. PP } \\
36\end{array}$ & 6.4 & 40 days & 58.4 & $\begin{array}{l}\text { Mangrove } \\
\text { sediment, } \\
\text { Malaysia }\end{array}$ & 82 \\
\hline Bacilli & $\begin{array}{l}\text { Bacillus cereus LDPE, HDPE } \\
\text { BF20 }\end{array}$ & 5,2 & 1 year & $5.0,2.0$ & Indian Ocean & 80 \\
\hline
\end{tabular}




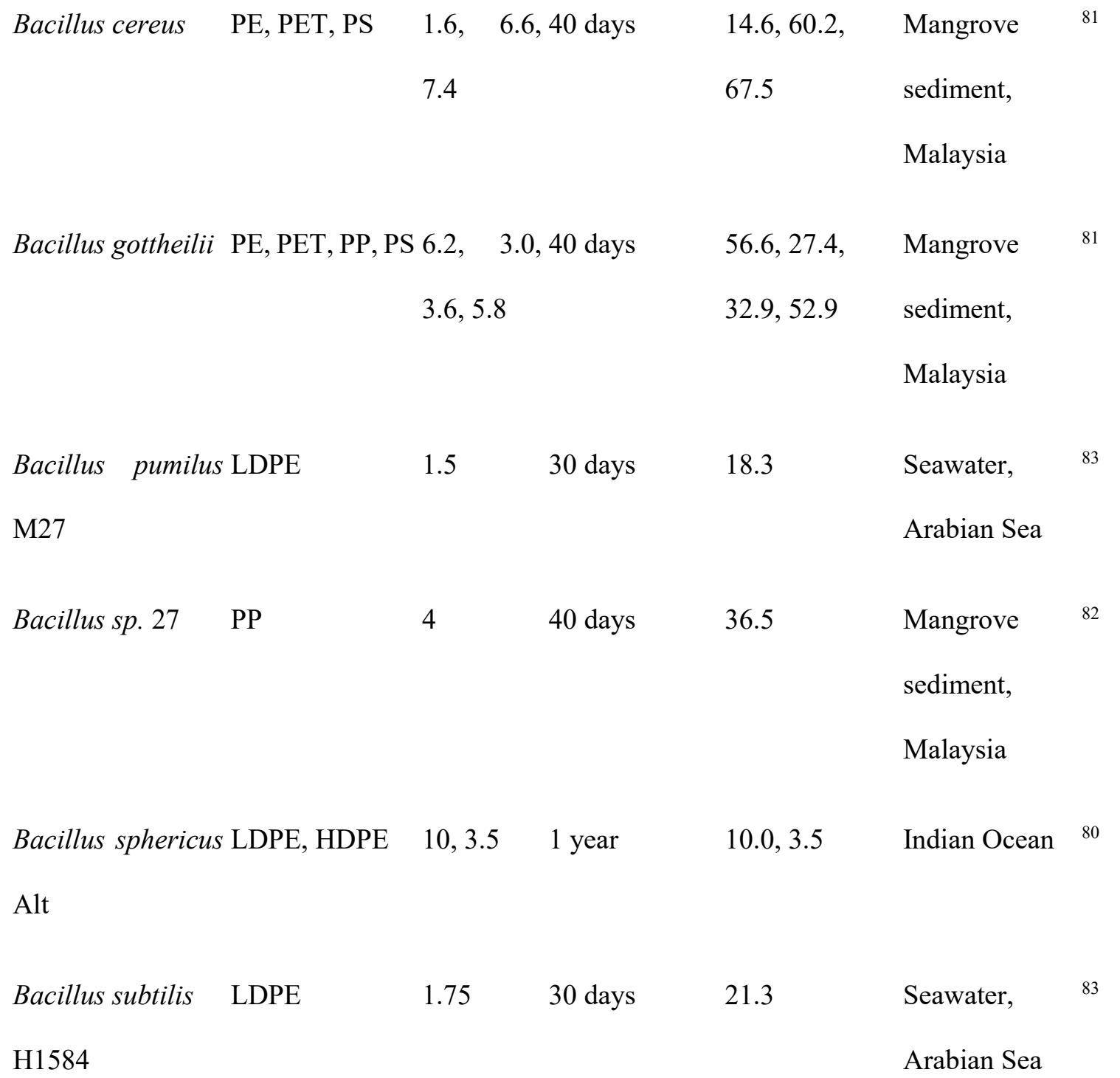

179 Additionally, microbial consortia with plastic-degrading activities have been investigated in

180 the laboratory. A synthetic community of four Vibrio strains showed biodegradation of polyvinyl

181 alcohol-low linear density polyethylene (PVA-LLDPE). ${ }^{84}$ Another consortium developed by

182 acclimatizing and bioaugmenting an indigenous community isolated from seawater was able to

183 degrade PE film with 19\% weight loss in 6 months. ${ }^{61}$ The effect of indigenous microbial

184 consortia on plastic submerged in seawater was detected as percentage weight loss of up to $2.5 \%$ 
185 in LDPE in six months, ${ }^{85} 1.6 \%$ in HDPE in 12 months, ${ }^{86} 0.6 \%$ in PP in six months, ${ }^{85} 30 \%$ in

186 nylon 4 in 3 weeks, ${ }^{87} 0.69 \%$ in polycarbonate (PC) in 12 months. ${ }^{86}$ While microorganisms

187 colonizing the plastic surfaces were observed, ${ }^{85,86}$ it should be noted that the respective

188 percentage weight losses cannot be exclusively attributed to biodegradation by these

189 microorganisms. Nevertheless, the findings indicate that the microbial communities colonizing

190 marine plastic litter are of interest in the search for plastic-degrading marine bacteria; however,

191 the identification and characterization of plastic-degrading pathways from the marine

192 environment remains to be awaited.

\section{Discussion}

194 Certain bacterial orders and families are repeatedly highlighted in an increasing number of 195 studies on the microbial communities colonizing marine plastic debris, giving rise to the term 196 "plastisphere" for this distinct habitat. ${ }^{31}$ This term has, however, also been challenged due to

197 variability in the plastisphere in regard to geographical and environmental differences ${ }^{35-37,58}$.

198 Harrison et al ${ }^{88}$ determined the taxonomy of bacteria colonizing LDPE in marine sediment in an 199 estuary and found two main genera; Colwellia and Arcobacter, which have not been found by 200 studies sampling plastic debris in the pelagic water column. It has been proposed that the core 201 microbiome differs depending on type or age of the plastic substrate, broadening the term 202 "plastisphere" for a specific microbial composition on marine plastic. ${ }^{38,59}$ On the other hand, 203 researchers have demonstrated the significant difference between the microbial communities on 204 marine plastic litter and the surrounding seawater and sediment at different geographical

205 locations such as the North Pacific Subtropical Gyre, the North Atlantic Subtropical Gyre, and 206 the North Sea. ${ }^{31,35,38,39}$ Furthermore, it was shown that bacterial communities attached to plastic 207 particles differed from those attached to a range of marine organic particles ${ }^{33}$ as well as cellulose 
208 and glass beads. ${ }^{40}$ However, others have found no significant difference in community

209 composition of bacteria colonizing plastic particles and glass beads, ${ }^{35}$ indicating that the

210 communities might form on any hard surface, not exclusively on plastic surfaces. This is a very

211 important aspect to be addressed in future research within this area. The plastic-associated

212 communities have certain bacterial families in common even across geographical locations

213 (Table 1), ${ }^{39}$ supporting the idea of a core microbiome native to the "plastisphere". Furthermore,

214 certain genes or taxon-associated functionalities are commonly enriched in the "plastisphere".

215 Often, this includes metabolic pathways associated with degradation of xenobiotics, ${ }^{39,56,59}$

216 indicating that bacteria colonizing plastic surfaces have common genomic traits and could

217 metabolically respond to the plastic, its additives or other adsorbed pollutants. Additionally,

218 some of the most commonly identified bacterial families associated with plastics, such as

219 Rhodobacteraceae and Hyphomonadaceae, also contain hydrocarbon-degrading members or

220 members previously associated with oil spills. ${ }^{39}$ As stated previously, ${ }^{36}$ the research community

221 should however be aware of environmental, geographical and surface-dependent differences in

222 the microbial community in future research efforts.

\section{5. Perspectives and Outlook for Marine Plastic Biodegradation}

224 While this perspective attempts to give an overview of a potential core microbiome on marine

225 plastic surfaces as well as marine plastic-degrading bacteria based on the presently available

226 data, it is evident that more data and research are needed. The current knowledge provides

227 indications for a core microbiome in the plastisphere, but in order to understand potential

228 degradation processes and to trace and potentially exploit marine plastic-degrading bacteria,

229 several steps of research are needed: 
5.1 Collection of Data. Currently available data originated from very limited geographic

231 areas in the Northern hemisphere (Figure 1). More data from different geographical locations,

232 particularly the continuously exposed plastic-polluted ocean areas such as the major ocean gyres,

233 as well as seasons and environments (sediment vs. pelagic waters) characterizing the unique

234 bacterial communities on plastics are needed. The next-generation sequencing approach of the

235 hypervariable regions of the $16 \mathrm{~S}$ rRNA gene, first introduced on the plastisphere by Zettler et

$236 a l .{ }^{31}$ will be sufficient to confirm the core microbiome on plastic. Efforts should be adapted to

237 protocols of the Earth Microbiome Project (http://www.earthmicrobiome.org/) to produce

238 consistent data comparable across different experiments and sampling sites. ${ }^{89}$ Furthermore,

239 future studies should collect data on colonization of non-plastic surfaces along with plastic

240 surfaces for comparison of the bacterial communities, similar to the approach of Oberbeckmann

241 et al. ${ }^{35}$ Time series of plastic colonization patterns should be analyzed similar to those conducted

242 on other marine particles such as chitin to elucidate the different roles of primary, secondary etc.

243 colonizers on the material and the overall biofilm structure. ${ }^{90}$ These studies could clarify if the

244 bacteria in the plastiphere actually degrade or modify the material or simply use it as a surface

245 and grow on more readily available photosynthetically-produced carbohydrates. Metagenomic or

246 metatranscriptomic data that not only provide information on taxonomic, but also functional

247 units (present or expressed genes) as described by Bryant et al. ${ }^{39}$ will be important to assess the

248 potential of bacterial colonizers to degrade the plastic and discover novel plastic-degrading

249 pathways. ${ }^{91}$ This data can furthermore be utilized to screen for novel homologs of known plastic-

250 degrading enzymes. ${ }^{92,93}$ 


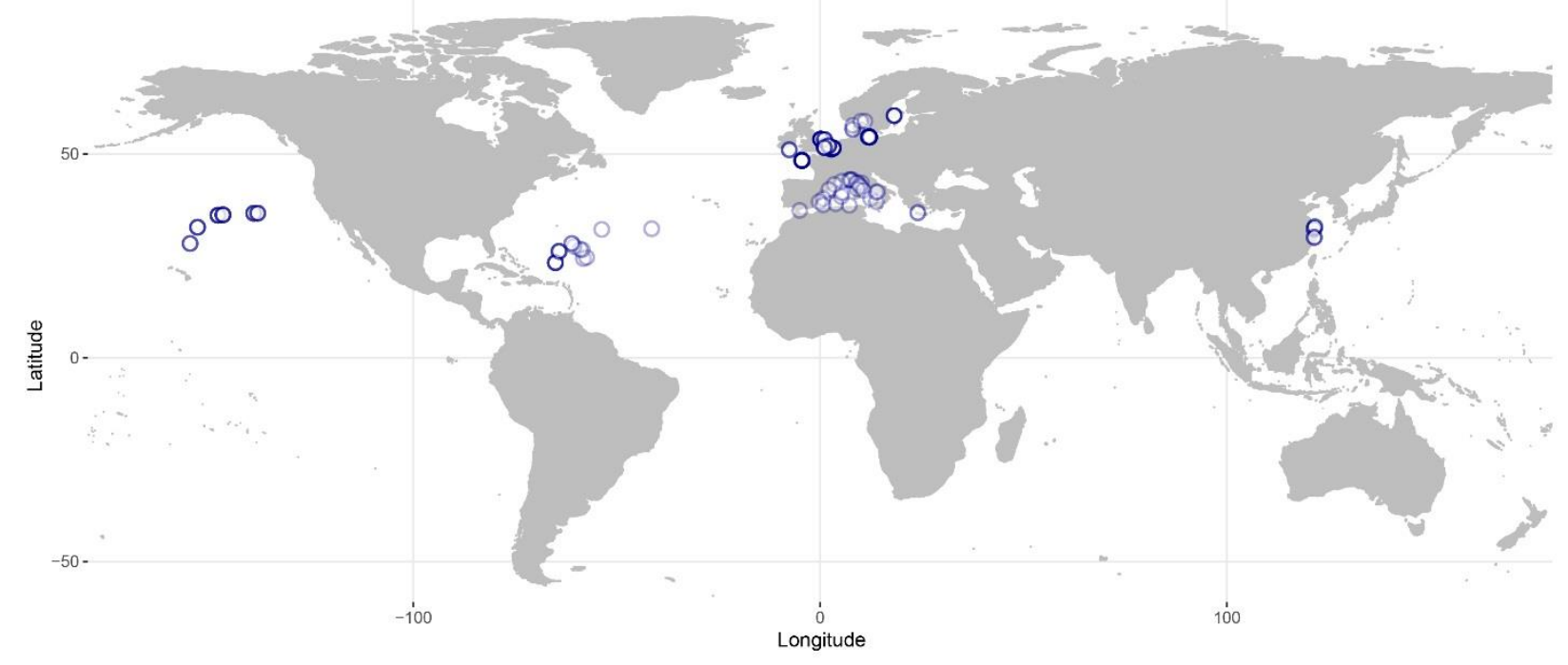

252 Figure 1. World map with sampling sites of currently available biodiversity data on marine 253 plastic debris (blue rings). ${ }^{31,33,35-40,55-59,88}$

$254 \quad 5.2$ Assessment of a Core Plastic-Degrading Microbiome. Based on sequence data 255 collected from marine plastic samples, a core microbiome for or core functionalities on marine 256 plastics should be investigated. This core microbiome might cover general marine plastic litter or 257 divide into sub-groups by season, geography or plastic type based on the statistical significance 258 levels of data collected.

$259 \quad 5.3$ Search for Plastic-Degrading Bacteria or Consortia. With a core microbiome assessed, 260 a qualified search for marine plastic-degrading bacteria or consortia can be conducted. This 261 research will most likely be based on culture-dependent methods or on bioinformatic analyses of 262 -omic data from marine plastic samples. Ultimately, any bioinformatic results will be followed 263 up by culture-dependent methods by necessity to establish whether plastic degradation occurs in 264 vivo. The core microbiome and associated degradation tests will furthermore indicate if bacteria 
265 indeed contribute to the fate of plastic in the marine environment and if natural bioremediation

266 does occur.

\subsection{Optimization and Implementation of Plastic-Degrading Bacteria and their Enzymes.}

268 Following the isolation of plastic-degrading bacteria, the enzymes involved in plastic

269 degradation can be characterized, investigated, and optimized as previously shown. ${ }^{26,46}$

270 Investigation of the evolutionary origin of plastic-degrading enzymes will contribute to the

271 search for other plastic-degrading enzymes and development strategies. ${ }^{26,46}$ Optimization of

272 enzymes through acclimatization experiments, adaptive laboratory evolution and genetic or

273 protein engineering can also be performed to increase efficiency ${ }^{46,93,94}$. Utilization of plastic-

274 degrading enzymes for bioremediation purposes must go through careful risk assessment and

275 utilization of bacterial strains in the environment should be closely monitored and risk assessed

276 to control spread of their bioactivities. Biofilters entrapping live, plastic-degrading bacteria could

277 however provide an applicable method of bioremediation..$^{95}$ Application of plastic-degrading

278 pathways for the utilization of plastic as a feedstock for cell factories and their most appropriate

279 integration into host metabolism can be guided through metabolic reconstructions of the

280 production hosts ${ }^{96}$ and scaled up in bioreactors. ${ }^{97}$

$281 \quad 5.5$ Interdisciplinary Work. A key component of future work on biodegradation of plastic

282 will also be the collaboration of scientists from various disciplines next to microbiologists

283 including, but not limited to: Bioinformaticians and structural biologists to develop in silico

284 methods for the reliable identification of putative plastic-degrading enzymes and subsequent

285 precursor/monomer processing; material scientists and chemists to design fluorescently or

286 isotope labelled polymers or polymer stains ${ }^{98}$ to trace biodegradation processes; analytical

287 chemists, ecotoxicologists and oceanographers to provide the analytical and computational 
288 techniques to accurately measure and model concentration and distribution of plastic particles in

289 the environment; experts in methods to visually describe the biofilms on the plastic surface and

290 the decay of the polymer itself such as electron, confocal, and atomic force microscopy, Fourier

291 Transform Infrared (FTIR) and Raman spectroscopy.

292 Today, we have only scratched the surface of understanding the fate and impact of plastic in

293 the oceans, however, it is already apparent that plastic does affect the environment including the

294 bacteria associated with its surface. It will require joint scientific, interdisciplinary efforts to

295 assess if these bacteria influence the transport of plastic, change its polymeric structure or even

296 degrade it to use it as carbon source, but if this is the case, these bacteria would provide an

297 innovative, promising resource for future bioremediation and biotechnology.

299 AUTHOR INFORMATION

300 Corresponding Author

301 * Eva C. Sonnenschein; e-mail: evaso@bio.dtu.dk; Technical University of Denmark,

302 Department of Biotechnology and Biomedicine, Søltofts Plads 221, DK-2800 Kgs. Lyngby,

303 Denmark

\section{ORCID}

305 Line Roager 0000-0002-7033-7309

306 Eva C. Sonnenschein 0000-0001-6959-5100

\section{Author Contributions}

308 The manuscript was written through contributions of all authors. All authors have given approval 309 to the final version of the manuscript. 
311 The authors thank Sonja Oberbeckmann and Nikolaus Sonnenschein for critical comments on the

312 manuscript.

\section{ABBREVIATIONS}

314 LDPE low density polyethylene, HDPE high density polyethylene, PAH polycyclic aromatic

315 hydrocarbon, PC polycarbonate, PE polyethylene, PET polyethylene terephthalate, PP

316 polypropylene, PS polystyrene, PVA-LLDPE polyvinyl alcohol-low linear density polyethylene

\section{REFERENCES}

318 (1) PlasticsEurope. Plastics - the Facts 2017; 2017.

319 (2) Li, W. C.; Tse, H. F.; Fok, L. Plastic Waste in the Marine Environment: A Review of 320 Sources, Occurrence and Effects. Science of the Total Environment. October 2016, pp 333349.

322

(3) Barboza, L. G. A.; Gimenez, B. C. G. Microplastics in the Marine Environment : Current 323 Trends and Future Perspectives. Mar. Pollut. Bull. 2015, 97, 5-12.

324 (4) Nauendorf, A.; Krause, S.; Bigalke, N. K.; Gorb, E. V; Gorb, S. N.; Haeckel, M.; Wahl, M.;

(5) Jambeck, J. R.; Geyer, R.; Wilcox, C.; Siegler, T. R.; Perryman, M.; Andrady, A.; Narayan, 
331 (6) Auta, H. S.; Emenike, C. U.; Fauziah, S. H. Distribution and Importance of Microplastics in the Marine Environment: A Review of the Sources, Fate, Effects, and Potential Solutions. Environ. Int. 2017, 102, 165-176.

334 (7) Gewert, B.; Plassmann, M. M.; Macleod, M. Environmental Science Processes \& Impacts

Pathways for Degradation of Plastic Polymers Fl Oating in the Marine Environment.

(9) Hermabessiere, L.; Dehaut, A.; Paul-Pont, I.; Lacroix, C.; Jezequel, R.; Soudant, P.; Duflos, Environ. Sci. Process. Impacts 2015, 17, 1513-1521.

8) Teuten, E. L.; Saquing, J. M.; Knappe, D. R. U.; Rowland, S. J.; Barlaz, M. A.; Jonsson, S.; Bjo, A.; Thompson, R. C.; Galloway, T. S.; Yamashita, R.; et al. Transport and Release of Chemicals from Plastics to the Environment and to Wildlife. Philos. Trans. R. Soc. B 2009, 364, 2027-2045.

(10) Royer, S.-J.; Ferrón, S.; Wilson, S. T.; Karl, D. M. Production of Methane and Ethylene from Plastic in the Environment. PLoS One 2018, 13 (8), e0200574.

(11) Romera-Castillo, C.; Pinto, M.; Langer, T. M.; Álvarez-Salgado, X. A.; Herndl, G. J. Dissolved Organic Carbon Leaching from Plastics Stimulates Microbial Activity in the Ocean. Nat. Commun. 2018, 9 (1), 1430.

(12) Andrady, A. L. Persistence of Plastic Litter in the Oceans. In Marine Anthropogenic Litter; 2015; pp 57-72.

(13) Cozar, A.; Echevarria, F.; Gonzalez-Gordillo, J. I.; Irigoien, X.; Ubeda, B.; Hernandez- 
Leon, S.; Palma, A. T.; Navarro, S.; Garcia-de-Lomas, J.; Ruiz, A.; et al. Plastic Debris in the Open Ocean. Proc. Natl. Acad. Sci. 2014, 111 (28), 10239-10244.

354

355

356

357

358

359

360

361

362

363

364

365

366

367

368

369

370

371

372

(14) Lebreton, L.; Slat, B.; Ferrari, F.; Sainte-Rose, B.; Aitken, J.; Marthouse, R.; Hajbane, S.; Cunsolo, S.; Schwarz, A.; Levivier, A.; et al. Evidence That the Great Pacific Garbage Patch Is Rapidly Accumulating Plastic. Sci. Rep. 2018, 8 (1), 1-15.

(15) Duis, K.; Coors, A. Microplastics in the Aquatic and Terrestrial Environment: Sources (with a Specific Focus on Personal Care Products), Fate and Effects. Environ. Sci. Eur. 2016, 28 (1), 1-25.

(16) Eriksen, M.; Lebreton, L. C. M.; Carson, H. S.; Thiel, M.; Moore, C. J.; Borerro, J. C.; Galgani, F.; Ryan, P. G.; Reisser, J. Plastic Pollution in the World's Oceans: More than 5 Trillion Plastic Pieces Weighing over 250,000 Tons Afloat at Sea. PLoS One 2014, 9 (12), $1-15$.

(17) Krueger, M. C.; Harms, H.; Schlosser, D. Prospects for Microbiological Solutions to Environmental Pollution with Plastics. Appl. Microbiol. Biotechnol. 2015, 99 (21), $8857-$ 8874.

(18) Ghosh, S. K.; Pal, S.; Ray, S. Study of Microbes Having Potentiality for Biodegradation of Plastics. Environ. Sci. Pollut. Res. 2013, 20, 4339-4355.

(19) Danko, A. S.; Luo, M.; Bagwell, C. E.; Brigmon, R. L.; Freedman, D. L. Involvement of Linear Plasmids in Aerobic Biodegradation of Vinyl Chloride. Appl. Environ. Microbiol. 2004, 70 (10), 6092-6097.

(20) Nakajima-Kambe, T.; Onuma, F.; Kimpara, N.; Nakahara, T. Isolation and Characterization 
of a Bacterium Which Utilizes Polyester Polyurethane as a Sole Carbon and Nitrogen Source. FEMS Microbiol. Lett. 1995, 129, 39-42.

375

376

377

378

379

380

(21) Caruso, G. Plastic Degrading Microorganisms as a Tool for Bioremediation of Plastic Contamination in Aquatic Environments. J. Pollut. Eff. Control 2015, 3 (3), e112.

(22) Paço, A.; Duarte, K.; da Costa, J. P.; Santos, P. S. M.; Pereira, R.; Pereira, M. E.; Freitas, A. C.; Duarte, A. C.; Rocha-Santos, T. A. P. Biodegradation of Polyethylene Microplastics by the Marine Fungus Zalerion Maritimum. Sci. Total Environ. 2017, 586, 10-15.

(23) Gilan (Orr), I.; Hadar, Y.; Sivan, A. Colonization, Biofilm Formation and Biodegradation of Polyethylene by a Strain of Rhodococcus Ruber. Appl. Microb. Cell Physiol. 2004, 65, 97-104.

(24) Hadad, D.; Geresh, S.; Sivan, A. Biodegradation of Polyethylene by the Thermophilic Bacterium Brevibacillus Borstelensis. J. Appl. Microbiol. 2005, 98, 1093-1100.

(25) Balasubramanian, V.; Natarajan, K.; Hemambika, B.; Ramesh, N.; Sumathi, C. S.; Kottaimuthu, R. High-Density Polyethylene (HDPE) -Degrading Potential Bacteria from Marine Ecosystem of Gulf of Mannar, India. Lett. Appl. Microbiol. 2010, 51, 205-211.

(26) Yoshida, S.; Hiraga, K.; Takehana, T.; Taniguchi, I.; Yamaji, H.; Maeda, Y.; Toyohara, K.; Miyamoto, K.; Kimura, Y.; Oda, K. A Bacterium That Degrades and Assimilates Poly(Ethylene Terephthalate). Science (80-. ). 2016, 351 (6278), 1-5.

(27) Sekhar, V. C.; Nampoothiri, K. M.; Mohan, A. J.; Nair, N. R.; Bhaskar, T.; Pandey, A. Microbial Degradation of High Impact Polystyrene ( HIPS ), an e-Plastic with Decabromodiphenyl Oxide and Antimony Trioxide. J. Hazard. Mater. 2016, 318, 347-354. 
(28) Mohan, A. J.; Sekhar, V. C.; Bhaskar, T.; Nampoothiri, K. M. Bioresource Technology Microbial Assisted High Impact Polystyrene ( HIPS ) Degradation. Bioresour. Technol. 2016, 213, 204-207.

(29) Azeko, S. T.; Etuk-Udo, G. A.; Odusanya, O. S.; Malatesta, K.; Anuku, N.; Soboyejo, W. O. Biodegradation of Linear Low Density Polyethylene by Serratia Marcescens Subsp. Marcescens and Its Cell Free Extracts. Waste and Biomass Valorization 2015, 6 (6), 10471057.

(30) Kita, K.; Ishimaru, K.; Teraoka, M.; Yanase, H.; Kato, N. Properties of Poly (3Hydroxybutyrate) Depolymerase from a Marine Bacterium, Alcaligenes Faecalis AE122. Appl. Environ. Microbiol. 1995, 61 (5), 1727-1730.

(31) Zettler, E. R.; Mincer, T. J.; Amaral-Zettler, L. A. Life in the "Plastisphere": Microbial Communities on Plastic Marine Debris. Environ. Sci. Technol. 2013, 47, 7137-7146.

(32) Lobelle, D.; Cunliffe, M. Early Microbial Biofilm Formation on Marine Plastic Debris. Mar. Pollut. Bull. 2011, 62 (1), 197-200.

(33) Dussud, C.; Meistertzheim, A. L.; Conan, P.; Pujo-Pay, M.; George, M.; Fabre, P.; Coudane, J.; Higgs, P.; Elineau, A.; Pedrotti, M. L.; et al. Evidence of Niche Partitioning among Bacteria Living on Plastics, Organic Particles and Surrounding Seawaters. Environ. Pollut. 2018, 236, 807-816.

(34) Dussud, C.; Hudec, C.; George, M.; Fabre, P.; Higgs, P.; Bruzaud, S.; Delort, A. M. A.; Eyheraguibel, B.; Meistertzheim, A. A. L.; Jacquin, J.; et al. Colonization of NonBiodegradable and Biodegradable Plastics by Marine Microorganisms. Front. Microbiol. 
2018, 9 (JUL), 1-13.

416

417

418

419

420

421

422

423

424

425

426

427

428

429

430

431

432

433

434

435
(35) Oberbeckmann, S.; Osborn, A. M.; Duhaime, M. B. Microbes on a Bottle: Substrate, Season and Geography Influence Community Composition of Microbes Colonizing Marine Plastic Debris. PLoS One 2016, 11 (8), 1-24.

(36)

Oberbeckmann, S.; Loeder, M. G. J.; Gerdts, G.; Osborn, M. A.; Osborn, A. M. Spatial and Seasonal Variation in Diversity and Structure of Microbial Biofilms on Marine Plastics in Northern European Waters. FEMS Microbiol. Ecol. 2014, 49 (0), 478-492.

(37) Oberbeckmann, S.; Kreikemeyer, B.; Labrenz, M. Environmental Factors Support the Formation of Specific Bacterial Assemblages on Microplastics. Front. Microbiol. 2018, 8 (January), 2709.

(38) De Tender, C. A.; Devriese, L. I.; Haegeman, A.; Maes, S.; Ruttink, T.; Dawyndt, P. Bacterial Community Profiling of Plastic Litter in the Belgian Part of the North Sea. Environ. Sci. Technol. 2015, 49 (16), 9629-9638.

(39) Bryant, J. A.; Clemente, T. M.; Viviani, D. A.; Fong, A. A.; Thomas, K. A.; Kemp, P.; Karl, D. M.; White, A. E.; Delong, E. F. Diversity and Activity of Communities Inhabiting Plastic Debris in the North Pacific Gyre. mSystems 2016, 1 (3), 1-19.

(40) Ogonowski, M.; Motiei, A.; Ininbergs, K.; Hell, E.; Gerdes, Z.; Udekwu, K. I.; Bacsik, Z.; Gorokhova, E. Evidence for Selective Bacterial Community Structuring on Microplastics. Environ. Microbiol. 2018, 20 (8), 2796-2808.

(41) Hazen, T. C.; Dubinsky, E. A.; DeSantis, T. Z.; Andersen, G. L.; Piceno, Y. M.; Singh, N.; Jansson, J. K.; Probst, A.; Borglin, S. E.; Fortney, J. L.; et al. Deep-Sea Oil Plume Enriches 
Indigenous Oil-Degrading Bacteria. Science (80-. ). 2010, 330 (6001), 204-208.

437

438

439

440

441

442

443

444

445

446

447

448

449

450

451

452

453

454

455

456

(42) Lea-Smith, D. J.; Biller, S. J.; Davey, M. P.; Cotton, C. a. R.; Perez Sepulveda, B. M.; Turchyn, A. V.; Scanlan, D. J.; Smith, A. G.; Chisholm, S. W.; Howe, C. J. Contribution of Cyanobacterial Alkane Production to the Ocean Hydrocarbon Cycle. Proc. Natl. Acad. Sci. 2015, 201507274.

(43) Dvořák, P.; Nikel, P. I.; Damborský, J.; de Lorenzo, V. Bioremediation 3 . 0 : Engineering Pollutant-Removing Bacteria in the Times of Systemic Biology. Biotechnol. Adv. 2017, 35 (August), 845-866.

(44) Helm, E. Van Der; Genee, H. J.; Sommer, M. O. A. The Evolving Interface between Synthetic Biology and Functional Metagenomics. Nat. Chem. Biol. 2018, 14 (August), 19.

(45) Bhardwaj, H.; Gupta, R.; Tiwari, A. Microbial Population Associated With Plastic Degradation. Open Access Sci. Reports 2012, 1 (5), 10-13.

(46) Austin, H. P.; Allen, M. D.; Donohoe, B. S.; Rorrer, N. A.; Kearns, F. L.; Silveira, R. L.; Pollard, B. C.; Dominick, G.; Duman, R.; El Omari, K.; et al. Characterization and Engineering of a Plastic-Degrading Aromatic Polyesterase. Proc. Natl. Acad. Sci. 2018, 115 (19), E4350-E4357.

(47) Narancic, T.; O’Connor, K. E. Microbial Biotechnology Addressing the Plastic Waste Disaster. Microb. Biotechnol. 2017, 10 (5), 1232-1235.

(48) Kubowicz, S.; Booth, A. M. Biodegradability of Plastics: Challenges and Misconceptions. Environ. Sci. Technol. 2017, acs.est.7b04051. 
(49) Emadian, S. M.; Onay, T. T.; Demirel, B. Biodegradation of Bioplastics in Natural Environments. Waste Manag. 2017, 59, 526-536.

(50) Geyer, R.; Jambeck, J. R.; Law, K. L. Production, Uses, and Fate of All Plastics Ever Made. Sci. Adv. 2017, 3 (7), 5.

(51) Campbell, L.; Vaulot, D. Photosynthetic Picoplankton Community Structure in the Subtropical North Pacific Ocean near Hawaii (Station ALOHA). Deep. Res. I 1993, 40 (10), 2043-2060.

(52) Pérez, L. B.; Fenical, W. Accessing Marine Microbial Diversity for Drug Discovery. In Microbial Resources; Elsevier Inc., 2017; pp 169-187.

(53) Carpenter, E. J.; Anderson, S. J.; Harvey, G. R.; Miklas, H. P.; Peck, B. B. Polystyrene Spherules in Coastal Waters. Science (80-. ). 1972, 178 (4062), 749-750.

(54) Carpenter, E. J.; Smith Jr., K. L. Plastics on the Sargasso Sea Surface. Science (80-. ). 1972, 175 (4027), 1240-1241.

(55) Frère, L.; Maignien, L.; Chalopin, M.; Huvet, A.; Rinnert, E.; Morrison, H.; Kerninon, S.; Cassone, A. L.; Lambert, C.; Reveillaud, J.; et al. Microplastic Bacterial Communities in the Bay of Brest: Influence of Polymer Type and Size. Environ. Pollut. 2018, 242, 614 625.

(56) Syranidou, E.; Karka, K.; Amorotti, F.; Franchini, M.; Repouskou, E.; Kaliva, M.; Vamv, M.; Kolvenbach, B.; Fava, F.; Corvini, P. F.; et al. Biodegradation of Weathered Polystyrene Films in Seawater Microcosms. Sci. Rep. 2017, 7 (17991), 1-12.

(57) Pollet, T.; Berdjeb, L.; Garnier, C.; Durrieu, G.; Poupon, C. Le; Misson, B.; Briand, J.-F. 
Prokaryotic Community Successions and Interactions in Marine Biofilms: The Key Role of Flavobacteriia. FEMS Microbiol. Ecol. 2018, 94 (May), 1-13.

(58) Jiang, P.; Zhao, S.; Zhu, L.; Li, D. Microplastic-Associated Bacterial Assemblages in the Intertidal Zone of the Yangtze Estuary. Sci. Total Environ. 2018, 624, 48-54.

(59) Didier, D.; Anne, M.; Alexandra, T. H. Plastics in the North Atlantic Garbage Patch: A Boat-Microbe for Hitchhikers and Plastic Degraders. Sci. Total Environ. 2017, 599-600, $1222-1232$.

(60) Lee, O. O.; Chung, H. C.; Yang, J.; Wang, Y.; Dash, S.; Wang, H.; Qian, P. Y. Molecular Techniques Revealed Highly Diverse Microbial Communities in Natural Marine Biofilms on Polystyrene Dishes for Invertebrate Larval Settlement. Microb. Ecol. 2014, 68 (1), 8193.

(61) Syranidou, E.; Karkanorachaki, K.; Amorotti, F.; Repouskou, E.; Kroll, K.; Kolvenbach, B.; Corvini, P. F.; Fava, F.; Kalogerakis, N. Development of Tailored Indigenous Marine Consortia for the Degradation of Naturally Weathered Polyethylene Films. PLoS One 2017, $12(8), 1-21$.

(62) Smith, C. S.; Hinz, A.; Bodenmiller, D.; Larson, D. E.; Brun, Y. V. Identification of Genes Required for Synthesis of the Adhesive Holdfast in Caulobacter Crescentus. J. Bacteriol. 2003, $185(4), 1432-1442$.

(63) Dang, H.; Li, T.; Chen, M.; Huang, G. Cross-Ocean Distribution of Rhodobacterales Bacteria as Primary Surface Colonizers in Temperate Coastal Marine Waters. Appl. Environ. Microbiol. 2008, 74 (1), 52-60. 
(64) Zhuang, L.; Liu, Y.; Wang, L.; Wang, W.; Shao, Z. Erythrobacter Atlanticus Sp. Nov., a Bacterium from Ocean Sediment Able to Degrade Polycyclic Aromatic Hydrocarbons. Int. J. Syst. Evol. Microbiol. 2015, 65 (10), 3714-3719.

(65) Kumar Sen, S.; Raut, S. Microbial Degradation of Low Density Polyethylene (LDPE): A Review. J. Environ. Chem. Eng. 2015, 3 (1), 462-473.

(66) Shah, A. A.; Hasan, F.; Hameed, A.; Ahmed, S. Biological Degradation of Plastics: A Comprehensive Review. Biotechnol. Adv. 2008, 26 (3), 246-265.

(67) Zettler, E. R.; Mincer, T. J.; Amaral-zettler, L. A. Life in the " Plastisphere " : Microbial Communities on Plastic Marine Debris. Environ. Sci. Technol. 2013, 47, 7137-7146.

(68) Schneiker, S.; Dos Santos, V. A. P. M.; Bartels, D.; Bekel, T.; Brecht, M.; Buhrmester, J.; Chernikova, T. N.; Denaro, R.; Ferrer, M.; Gertler, C.; et al. Genome Sequence of the Ubiquitous Hydrocarbon-Degrading Marine Bacterium Alcanivorax Borkumensis. Nat. Biotechnol. 2006, 24 (8), 997-1004.

(69) Kirstein, I. V; Kirmizi, S.; Wichels, A.; Garin-Fernandez, A.; Erler, R.; Löder, M.; Gerdts, G. Dangerous Hitchhikers? Evidence for Potentially Pathogenic Vibrio Spp. on Microplastic Particles. Mar. Environ. Res. 2016, 120, 1-8.

(70) Hedlund, B. P.; Staley, J. T. Vibrio Cyclotrophicus Sp. Nov., a Polycyclic Aromatic Hydrocarbon (PAH)-Degrading Marine Bacterium. Int. J. Syst. Evol. Microbiol. 2001, 51 (1), 61-66.

(71) Hayes, C. A.; Dalia, T. N.; Dalia, A. B. Systematic Genetic Dissection of Chitin Degradation and Uptake in Vibrio Cholerae. Environ. Microbiol. 2017, 19(10), 4154-4163. 
(72) Giubergia, S.; Phippen, C.; Gotfredsen, C. H.; Nielsen, K. F.; Gram, L. Influence of NicheSpecific Nutrients on Secondary Metabolism in Vibrionaceae. Appl. Environ. Microbiol. 2016, 82 (13), 4035-4044.

(73) Juhasz, A. L.; Britz, M. L.; Stanley, G. A. Degradation of Benzo[a]Pyrene, Dibenz[a,h]Anthracene and Coronene by Burkholderia Cepacia. Water Sci. Technol. 1997, $36(10), 45-51$.

(74) Brinkhoff, T.; Fischer, D.; Vollmers, J.; Voget, S.; Beardsley, C.; Thole, S.; Mussmann, M.; Kunze, B.; Wagner-Döbler, I.; Daniel, R.; et al. Biogeography and Phylogenetic Diversity of a Cluster of Exclusively Marine Myxobacteria. ISME J. 2012, 6 (6), 1260-1272.

(75) Sekiguchi, T.; Saika, A.; Nomura, K.; Watanabe, T.; Watanabe, T.; Fujimoto, Y.; Enoki, M.; Sato, T.; Kato, C.; Kanehiro, H. Biodegradation of Aliphatic Polyesters Soaked in Deep Seawaters and Isolation of Poly(e-Caprolactone)-Degrading Bacteria. Polym. Degrad. Stab. 2011, 96 (7), 1397-1403.

(76) Leys, N. M. E. J.; Ryngaert, A.; Bastiaens, L.; Verstraete, W.; Top, E. M.; Springael, D. Occurrence and Phylogenetic Diversity of Sphingomonas Strains in Soils Contaminated with Polycyclic Aromatic Hydrocarbons. Appl. Environ. Microbiol. 2004, 70 (4), 19441955.

(77) Anti, M. P.; Jovan, B. S.; Ili, M.; Vrvi, M. M.; Schwarzbauer, J. Petroleum Pollutant Degradation by Surface Water Microorganisms. Pet. Pollut. Degrad. 2006, 13 (5), 320327.

(78) Jacquin, J.; Cheng, J.; Odobel, C.; Pandin, C.; Conan, P.; Pujo-Pay, M.; Barbe, V.; 
Meistertzheim, A.-L.; Ghiglione, J.-F. Microbial Ecotoxicology of Marine Plastic Debris:

A Review on Colonization and Biodegradation by the "Plastisphere." Front. Microbiol. 2019, 10 (April), 1-16.

544

(79) Wierckx, N.; Narancic, T.; Eberlein, C.; Wei, R.; Drzyzga, O.; Magnin, A.; Ballerstedt, H.; Kenny, S. T.; Pollet, E.; Averous, L.; et al. Plastic Biodegradation: Challenges and Opportunities. In Handbook of Hydrocarbon and Lipid Microbiology Consequences; 2018; pp 1-30.

(80) Sudhakar, M.; Doble, M.; Murthy, P. S.; Venkatesan, R. Marine Microbe-Mediated Biodegradation of Low- and High-Density Polyethylenes. Int. Biodeterior. Biodegradation 2008, 61, 203-213.

(81) Auta, H. S.; Emenike, C. U.; Fauziah, S. H. Screening of Bacillus Strains Isolated from Mangrove Ecosystems in Peninsular Malaysia for Microplastic Degradation. Environ. Pollut. 2017, 231, 1552-1559.

(82) Auta, H. S.; Emenike, C. U.; Jayanthi, B.; Fauziah, S. H. Growth Kinetics and Biodeterioration of Polypropylene Microplastics by Bacillus Sp. and Rhodococcus Sp. Isolated from Mangrove Sediment. Mar. Pollut. Bull. 2018, 127 (April 2017), 15-21.

(83) Harshvardhan, K.; Jha, B. Biodegradation of Low-Density Polyethylene by Marine Bacteria from Pelagic Waters, Arabian Sea, India. Mar. Pollut. Bull. 2013, 77 (1-2), 100-106.

(84) Raghul, S. S.; Bhat, S. G.; Chandrasekaran, M.; Francis, V.; Thachil, E. T. Biodegradation of Polyvinyl Alcohol-Low Linear Density Polyethylene-Blended Plastic Film by Consortium of Marine Benthic Vibrios. Int. J. Environ. Sci. Technol. 2014, 11, 1827-1834. 
(85) Sudhakar, M.; Trishul, A.; Doble, M.; Kumar, K. S.; Jahan, S. S.; Inbakandan, D.; Viduthalai, R. R.; Umadevi, V. R.; Murthy, P. S.; Venkatesan, R. Biofouling and Biodegradation of Polyolefins in Ocean Waters. Polym. Degrad. Stab. 2007, 92, 17431752.

(86) Artham, T.; Sudhakar, M.; Venkatesan, R.; Nair, C. M.; Murty, K. V. G. K.; Doble, M. Biofouling and Stability of Synthetic Polymers in Sea Water. Int. Biodeterior. Biodegradation 2009, 63 (7), 884-890.

(87) Tachibana, K.; Urano, Y.; Numata, K. Biodegradability of Nylon 4 Film in a Marine Environment. Polym. Degrad. Stab. 2013, 98, 1847-1851.

(88) Harrison, J. P.; Schratzberger, M.; Sapp, M.; Osborn, A. M. Rapid Bacterial Colonization of Low-Density Polyethylene Microplastics in Coastal Sediment Microcosms. BMC Microbiol. 2014, 14 (232), 1-15.

(89) Thompson, L. R.; Sanders, J. G.; McDonald, D.; Amir, A.; Ladau, J.; Locey, K. J.; Prill, R. J.; Tripathi, A.; Gibbons, S. M.; Ackermann, G.; et al. A Communal Catalogue Reveals Earth's Multiscale Microbial Diversity. Nature 2017, 551, 457-463.

(90) Enke, T. N.; Datta, M. S.; Schwartzman, J.; Cermak, N.; Schmitz, D.; Barrere, J.; PascualGarcía, A.; Cordero, O. X. Modular Assembly of Polysaccharide-Degrading Marine Microbial Communities. Curr. Biol. 2019, 29 (9), 1528-1535.e6.

(91) Knight, R.; Vrbanac, A.; Taylor, B. C.; Aksenov, A.; Callewaert, C.; Debelius, J.; Gonzalez, A.; Kosciolek, T.; McCall, L. I.; McDonald, D.; et al. Best Practices for Analysing Microbiomes. Nat. Rev. Microbiol. 2018, 16 (7), 410-422. 
(92) Hajighasemi, M.; Tchigvintsev, A.; Nocek, B.; Flick, R.; Popovic, A.; Hai, T.; Khusnutdinova, A. N.; Brown, G.; Xu, X.; Cui, H.; et al. Screening and Characterization of Novel Polyesterases from Environmental Metagenomes with High Hydrolytic Activity against Synthetic Polyesters. Environ. Sci. Technol. 2018, 52 (21), 12388-12401.

(93) Danso, D.; Schmeisser, C.; Chow, J.; Zimmermann, W.; Wei, R.; Leggewie, C.; Li, X.; Hazen, T.; Streit, W. R. New Insights into the Function and Global Distribution of Polyethylene Terephthalate (PET) -Degrading Bacteria and Enzymes in Marine and Terrestrial Metagenomes. Appl. Environ. Microbiol. 2018, 84 (8), 1-13.

(94) Arnold, F. H. Directed Evolution: Bringing New Chemistry to Life. Angew. Chemie - Int. Ed. 2018, 57 (16), 4143-4148.

(95) Tong, H. W.; Mutlu, B. R.; Wackett, L. P.; Aksan, A. Manufacturing of Bioreactive Nanofibers for Bioremediation. Biotechnol. Bioeng. 2014, 111 (8), 1483-1493.

(96) Cardoso, J. G. R.; Jensen, K.; Lieven, C.; Hansen, A. S. L.; Galkina, S.; Beber, M.; Özdemir, E.; Herrgård, M. J.; Redestig, H.; Sonnenschein, N. Cameo: A Python Library for Computer Aided Metabolic Engineering and Optimization of Cell Factories. ACS Synth. Biol. 2018, 7 (4), 1163-1166.

(97) Bao, J.; Ye, Q.; Zhong, J.-J. Bioreactor Engineering Research and Industrial Applications II; Bao, J., Ye, Q., Zhong, J.-J., Eds.; Advances in Biochemical Engineering/Biotechnology; Springer Berlin Heidelberg, 2016; Vol. 152.

(98) Erni-Cassola, G.; Gibson, M. I.; Thompson, R. C.; Christie-Oleza, J. A. Lost, but Found with Nile Red: A Novel Method for Detecting and Quantifying Small Microplastics (1 Mm 
604 to $20 \mathrm{Mm}$ ) in Environmental Samples. Environ. Sci. Technol. 2017, 51 (23), 13641-13648.

605

606 TOC

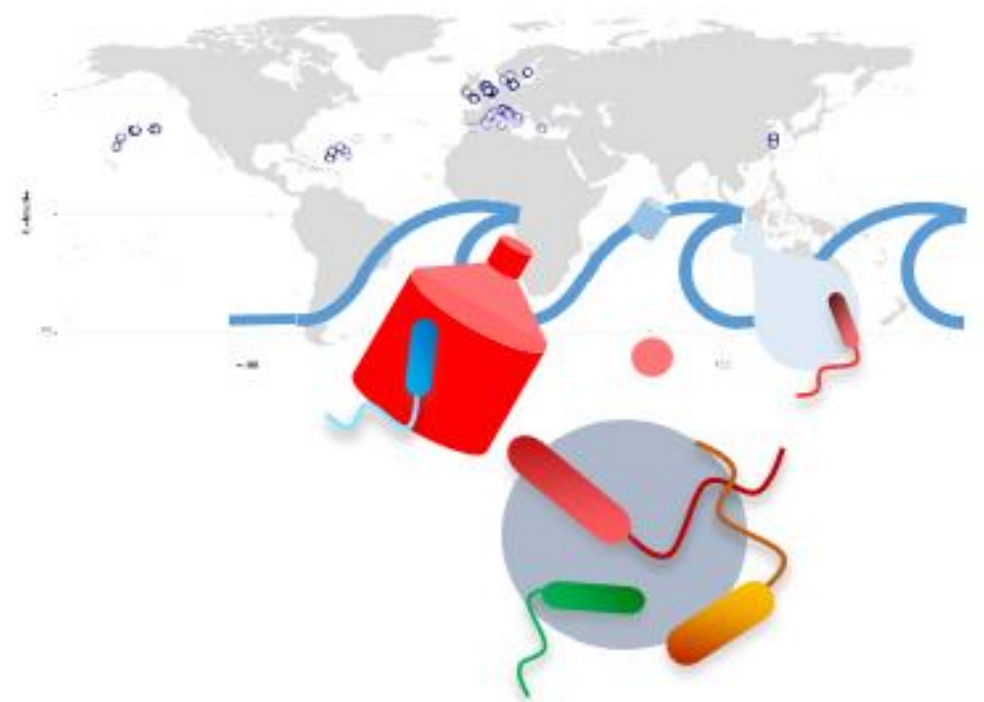

607 